\title{
Androgen-Regulated microRNAs (AndroMiRs) as Novel Players in Adipogenesis
}

\author{
Julia Jansen ${ }^{\dagger}$, Thomas Greither ${ }^{\dagger}(\mathbb{B})$ and Hermann M. Behre * \\ Center for Reproductive Medicine and Andrology, Martin Luther University Halle-Wittenberg, \\ 06120 Halle (Saale), Germany; julia.jansen@uk-halle.de (J.J.); thomas.greither@medizin.uni-halle.de (T.G.) \\ * Correspondence: hermann.behre@medizin.uni-halle.de; Tel.: +49-345-557-4782 \\ + These authors contributed equally to this work.
}

Received: 1 November 2019; Accepted: 12 November 2019; Published: 16 November 2019

\begin{abstract}
The development, homeostasis, or increase of the adipose tissue is driven by the induction of the adipogenic differentiation (adipogenesis) of undifferentiated mesenchymal stem cells (MSCs). Adipogenesis can be inhibited by androgen stimulation of these MSCs resulting in the transcription initiation or repression of androgen receptor (AR) regulated genes. AR not only regulates the transcription of protein-coding genes but also the transcription of several non-coding microRNAs involved in the posttranscriptional gene regulation (herein designated as AndroMiRs). As microRNAs are largely involved in differentiation processes such as adipogenesis, the involvement of AndroMiRs in the androgen-mediated inhibition of adipogenesis is likely, however, not yet intensively studied. In this review, existing knowledge about adipogenesis-related microRNAs and AndroMiRs is summarized, and putative cross-links are drawn, which are still prone to experimental validation.
\end{abstract}

Keywords: androgens; adipogenesis; microRNA

\section{Introduction}

Androgen regulation of gene transcription is mediated through testosterone, or the more bioactive derivate dihydrotestosterone (DHT), or any other androgenic hormone binding to the androgen receptor (AR), followed by intra-nuclear binding of the ligand-activated AR to androgen-responsive elements (ARE) in the promoter region of the respective gene and subsequent transcription initiation or repression by AR-recruited cofactors [1,2]. These genes do not necessarily have to be protein-coding, as the transcription of several non-coding genes has been shown to be regulated by the AR [3-5]. On a somatic level, several tissues including prostate, muscle, liver, breast, ovaries or fat are prone to androgen action [6-9]. With respect to adipose tissue, testosterone and DHT were demonstrated to inhibit the adipogenic differentiation (adipogenesis) of mouse and human mesenchymal stem cells [10-14].

Adipogenesis designates the differentiation process of a mesenchymal progenitor cell to a mature adipocyte. In the times of increasing obesity prevalence, it is of utmost importance to understand the process of adipogenic differentiation, as the excessive proliferation of the body's fat mass is strongly associated with serious adverse conditions such as type 2 diabetes, mellitus, and cardiovascular diseases. The general developmental process of adipose tissue is composed of two components: (1) the increase of adipocyte numbers by differentiation (hyperplasia), and (2) the swelling of the single-cell by accumulation of triglycerides (hypertrophy). On the cellular level, at first mesenchymal stem cells (MSCs) are recruited through abrogation of the differentiation block (commitment phase), and subsequently differentiate to the mature adipocyte (terminal differentiation phase, see Figure 1). 


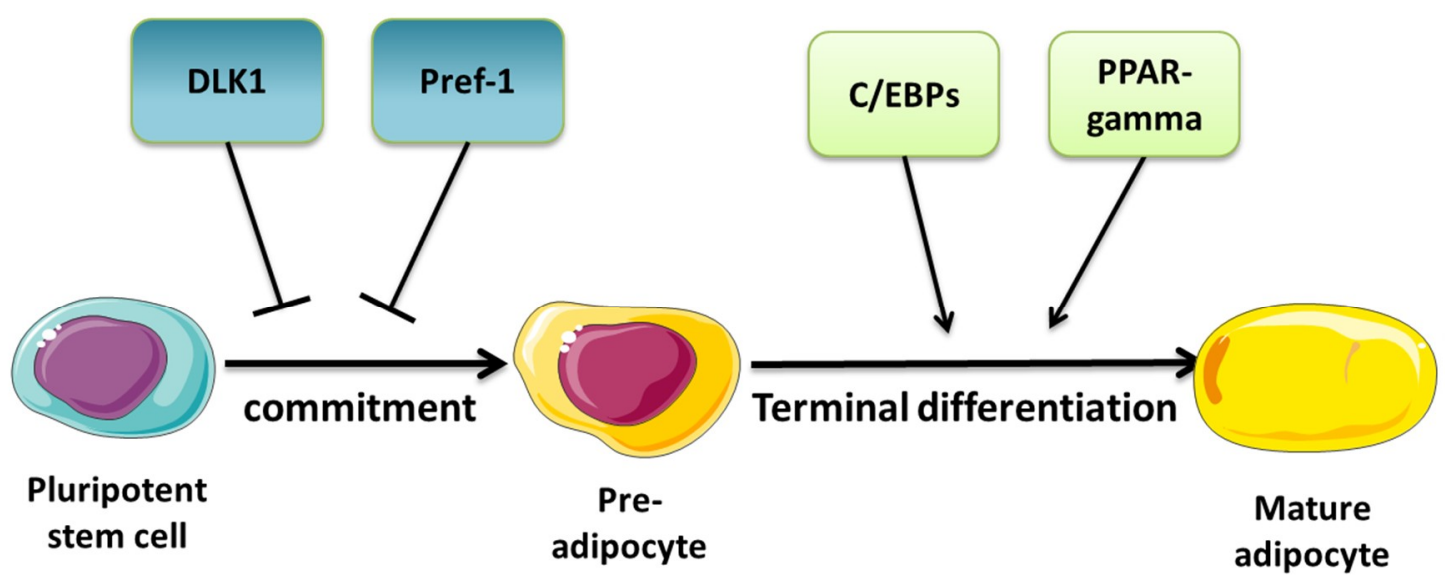

Figure 1. Phases of the adipogenic differentiation. Abbreviations: DLK1-delta-like homolog 1, Pref-1-preadipocyte factor 1 .

On the molecular level, especially two master regulators of adipogenesis are essential for differentiation: the transcription factors peroxisome proliferator-activated receptor gamma (PPAR $\gamma$ ) and CCAAT/enhancer-binding protein alpha $(\mathrm{CEBP} \alpha)$, which both induce a plethora of different adipocyte-specific genes during the commitment phase of differentiation [15]. Furthermore, an essential signaling pathway for the induction of adipogenesis by PPAR $\gamma$ is the Wnt pathway [16]. Mesenchymal progenitor cells are kept in an undifferentiated state by the canonical Wnt pathway through the induction of cyclin-D1 and c-myc. This differentiation block is mediated through the direct binding of c-myc on the DNA sequence of PPAR $\gamma$ and C/EBP $\alpha$ following inhibition of transcription. By such mechanisms, canonical Wnt10b and Wnt1 are capable of inhibiting the expression of PPAR $\gamma$ and blocking adipocytic differentiation $[17,18]$.

On the other hand, several signaling pathways like the MAPK pathway, the PI3K/Akt pathway, the cAMP/PKA/CREB pathway, and the TGF- $\beta$ pathway play an adipogenesis-promoting role after induction of the differentiation program within the commitment phase [19]. In recent years, by the identification and analysis of microRNAs, an additional player for the regulation of these different signaling pathways on the post-transcription level has been unraveled. MicroRNAs are small (18-25 nt long), endogenous RNAs, that are non-coding but involved in the post-transcriptional silencing of gene expression by translation inhibition [20]. Also during adipocytic differentiation, a subset of microRNAs are differentially expressed and subsequently regulate the differentiation course by inducing a massive shift in the cellular phenotype by changes in the expression patterns of their downstream target genes.

Actually, adipogenesis-regulating microRNAs and androgen-regulated microRNAs (AndroMiRs) could still be seen as "two separated kingdoms". However, by connecting adipogenesis-related microRNAs to those prone to androgen-regulation, interesting candidates for the molecular mechanisms of the well-known hypogonadism-induced fat tissue accumulation as well as potential therapeutic targets against this detrimental process might be identified. In this review, we aim to summarize the existing literature on both microRNA kingdoms and show potential connections between both of them.

\section{MicroRNAs in Human Mesenchymal Stem Cell Adipogenesis}

In the past years, over 30 microRNAs or microRNA families have been identified to be involved in the adipogenic differentiation process in human mesenchymal stem cells or preadipocytic cell lines (see Table 1). Furthermore, extensive studies on mouse cell lines or other species have revealed several more candidate microRNAs yet to be verified in human cells (see Tables S1 and S2). 
Table 1. Adipogenesis-regulating microRNAs in human cell lines/preadipocytes.

\begin{tabular}{|c|c|c|c|c|}
\hline microRNA & $\begin{array}{c}\text { Effect on } \\
\text { Adipogenesis }\end{array}$ & Cell System & $\begin{array}{c}\text { Target Gene/ } \\
\text { Signaling Pathway }\end{array}$ & Reference \\
\hline $\mathrm{miR}-10 \mathrm{~b}$ & $\mathrm{i}$ & hADSC & $\mathrm{CEBP} \alpha, \operatorname{PPAR} \gamma, \mathrm{AP} 2$ & Li et al., 2018 [21] \\
\hline $\operatorname{mir}-17-5 p / 106 a$ & $\mathrm{p}$ & hADSC & BMP2 & Li et al., 2013 [22] \\
\hline miR-21 & $\mathrm{p}$ & hMSC & SPRY2 & Mei et al., 2013 [23] \\
\hline $\mathrm{miR}-26 \mathrm{~b}$ & $\mathrm{p}$ & hADSC & PTEN & $\begin{array}{l}\text { Song et al., } 2014 \text { [24]; } \\
\text { Trohatou et al., } 2017 \text { [25] }\end{array}$ \\
\hline $\operatorname{miR}-27 b$ & $\mathrm{i}$ & hMSC & $\operatorname{PPAR} \gamma$ & Karbiener et al., 2009 [26] \\
\hline $\operatorname{miR}-27 b$ & $\mathrm{i}$ & hADSC & $\mathrm{LPL}, \mathrm{CEBP} \alpha, \mathrm{PPAR} \gamma$ & Hu et al., 2018 [27] \\
\hline miR-29 & $\mathrm{i}$ & hMSC & Cyclin D1 & Beezhold et al., 2016 [28] \\
\hline miR-29b & $\mathrm{p}$ & hADSC & TNF- $\alpha$ SP-1 & Zhang et al., 2016 [29] \\
\hline miR-30 family & $\mathrm{p}$ & hMADS & RUNX2 & Zaragosi et al., 2011 [30] \\
\hline $\mathrm{miR}-30 \mathrm{c}$ & $\mathrm{p}$ & hMADS & PAI-1, ALK2 & Karbiener et al., 2011 [31] \\
\hline miR-31 & $\mathrm{i}$ & hADSC & $\mathrm{CEBP} \alpha$ & Liu et al., 2018 [32] \\
\hline miR-103 & $\mathrm{p}$ & hADSC & Thy1 (CD90) & Woeller et al., 2017 [33] \\
\hline miR-107 & $\mathrm{i}$ & SGBS & CDK6 & Ahonen et al., 2019 [34] \\
\hline miR-124 & $\mathrm{p}$ & hMSC & FABP4, PPAR $\gamma$, SOX9 & Laine et al., 2012 [35] \\
\hline miR-125a-3p & $\mathrm{p}$ & hADSC & RhoA/ROCK1/ERK1/2 & Chen et al., 2015 [36] \\
\hline miR-125b-5p & $\mathrm{p} / \mathrm{i}$ & SGBS & MMP11 & Rockstroh et al., 2016 [37] \\
\hline miR-130 & $\mathrm{i}$ & hMSC & $\operatorname{PPAR} \gamma$ & Lee et al., 2011 [38] \\
\hline $\operatorname{miR}-137$ & $\mathrm{i}$ & hADSC & CDC42 & Shin et al., 2014 [39] \\
\hline miR-140-5p & $\mathrm{i}$ & hMSC & LIFR & Li et al., 2017 [40] \\
\hline miR-148a & $\mathrm{p}$ & hMSC & Wnt1 & Shi et al., 2015 [41] \\
\hline miR-149-3p & $\mathrm{i}$ & BMSC & FTO & Li et al., 2019 [42] \\
\hline miR-155 & $\mathrm{i}$ & hMSC & $\operatorname{PPAR} \gamma, \mathrm{CEBP} \alpha$ & Skarn et al., 2012 [43] \\
\hline miR-192-3p & $\mathrm{i}$ & hADSC & SCD, ALDH3H2 & Mysore et al., 2016 [44] \\
\hline miR-193b & $\mathrm{p}$ & hADSC & CRKL, FAK & Mazzu et al., 2017 [45] \\
\hline miR-194 & $\mathrm{i}$ & hMSC & COUP-TFII & Jeong et al., 2014 [46] \\
\hline miR-199a-3p & $\mathrm{p}$ & BMMSC & KDM6A & Shuai et al., 2019 [47] \\
\hline miR-204-5p & $\mathrm{p}$ & hADSC & DVL3 & He et al., 2015 [48] \\
\hline miR-320 fam. & $\mathrm{p}$ & hMSC & RUNX2 & Hamam et al., 2014 [49] \\
\hline miR-335 & $\mathrm{p}$ & hADSC & MEST & Zhu et al., 2014 [50] \\
\hline miR-342-3p & $\mathrm{p}$ & hMSC & CtBP2 & Wang et al., 2015 [51] \\
\hline $\mathrm{miR}-363$ & $\mathrm{p}$ & hADSC & E2F3 & Chen et al., 2014 [52] \\
\hline miR-369-5p & $\mathrm{i}$ & hMSC & FABP4 & Bork et al., 2011 [53] \\
\hline $\operatorname{miR}-375$ & $\mathrm{i}$ & SGBS & ADIPOR2 & Kraus et al., 2015 [54] \\
\hline miR-377-3p & $\mathrm{i}$ & hMSC & LIFR & Li et al., 2018 [55] \\
\hline miR-431 & $\mathrm{i}$ & BMMSC & IRS2 & Wang et al.,2018 [56] \\
\hline miR-483-5p & $\mathrm{p}$ & hADSC & RhoA/ROCK1/ERK1/2 & Chen et al., 2015 [36] \\
\hline $\mathrm{miR}-1908$ & $\mathrm{i}$ & hMADS & $\operatorname{PPAR} \gamma, \mathrm{CEBP} \alpha$ & Yang et al., 2015 [57] \\
\hline miR-1275 & $\mathrm{i}$ & hADSC & ELK1 & Pang et al., 2016 [58] \\
\hline miR-4739 & $\mathrm{p}$ & hMSC & LRP3 & Elsafadi et al., 2017 [59] \\
\hline
\end{tabular}

Abbreviations: $p$ - promoting effect, i—inhibiting effect, hADSC—human adipose-derived stem cells, hMSC—human mesenchymal stem cell, SGBS—Simpson Golabi Behmel syndrome cells, BMMSC—bone marrow-derived stem cells, hMADS-human multipotent adipose-derived stem cells.

$\mathrm{Li}$ et al. identified miR-10b as a critical regulator for balancing osteogenic and adipogenic differentiation of human adipose-derived stem cells (hADSCs) by repressing 'mothers against decapentaplegic homolog 2' (SMAD2) [21]. Its expression is negatively correlated to adipogenic markers like CEBP $\alpha$, PPAR $\gamma$ and activating protein 2 (AP2). In 3T3-L1 cells, apolipoprotein 6 (Apol6), which acts as an oncogene in obesity-related cancers, was identified as further target of miR-10b-5p. Inhibition of miR-10b-5p encouraged the adipogenic differentiation of 3T3-L1 cells. However, it has no effect on cell proliferation [60]. Similarly, the overexpression of miR-27b blunts the induction of the two key regulators CEBP $\alpha$ and PPAR $\gamma$ and represses triglyceride accumulation at the late stages of adipogenic differentiation [26]. Kim et al. confirmed these results by demonstrating a similar action of miR-27a in the 3T3-L1 cell adipogenesis of obese mice [61]. Accordingly, Hu et al. showed in microarray analysis an increase of lipoproteinlipase (LPL) during adipogenic differentiation of hADSCs, while miR-27b is decreased [27]. In addition, miR-130a and miR-130b influence the PPAR $\gamma$ expression in human preadipocytes. QPCR arrays showed that miR-130a/b targeted both the mRNA coding region as well as the 3'untranslated region of PPAR $\gamma$ [38]. These effects were also replicated in mouse 3T3-L1 
preadipocytes. Further microRNAs that inhibit the expression of PPAR $\gamma$ and C/EBPs and lead to an obstructed adipogenic differentiation in hMSCs are for example miR-155, miR-221 and miR-222 [43].

Yang et al. studied the effect of miR-1908 on the differentiation on hMADS. MiR-1908 is highly expressed in human multipotent adipose-derived stem cells (hMADS) and inhibits adipocyte differentiation by promoting the proliferation of hMADS cells and influencing the cell cycle through expanding the S phase and inhibiting the G1 phase [57]. Recently, studies with Simpson Golabi Behmel syndrome (SGBS) cells were conducted. For example, miR-107 inhibits adipogenic differentiation of SGBS cells via cell division protein kinase 6 (CDK6), which regulates neurogenic locus notch homolog protein 3 (Notch3) and his target 'hairy and enhancer of spli-1' (Hes1). Furthermore, miR-107 induces the attenuated triglyceride storage by impairing glucose uptake and triglyceride synthesis [34]. Adiponectin receptor 2 (ADIPOR2), a direct target of miR-375, has an inhibiting effect on the adipogenic differentiation of SBGS cells, too. Kraus et al. showed the inhibiting effect of androgens on adipogenic differentiation through an androgen receptor-mediated pathway [54]. Bork et al. performed investigations regarding miR-369-5p, which both impaired the proliferation of human MSCs and enhanced the accumulation of lipid droplets during adipogenic differentiation.

Accordingly, the expression of adiponectin (ADIPOQ) and 'fatty acid-binding protein 4' (FABP4) is reduced during differentiation after transfection with miR-369-5p [53]. MiR-149-3p inhibits adipogenic differentiation in BMSC by directly targeting 'fat mass and obesity-associated protein' (FTO). Knockdown of miR-149-3p led to a decreased expression of adipocyte-related genes including $\mathrm{CEBP} \alpha, \mathrm{CEBP} \beta, \mathrm{CEBP} \delta, \mathrm{FABP} 4$ and PPAR $\gamma$, whereas osteogenic markers like alkaline phosphatase (ALP), 'bone gamma-carboxyglutamic acid-containing protein' (BGLAP), secreted phosphoprotein 1 (SPP1), collagen type 1 (COL1A1), and 'bone morphogenetic protein 4' (BMP4) increased. MiR-149-3p also acts as a regulator of the switch between adipogenic and osteogenic differentiation [42]. Similar effects were observed for miR-194 and its target gene COUP transcription factor II (COUP-TFII), which activates PPAR $\gamma$ expression. Enhanced expression of miR-194 leads to a reduced expression of COUP-TFII, whereas inhibition of the miR-194 expression leads to an increased COUP-TFII level [46]. In contrast, miR-17-5p and miR-106a could promote osteogenesis and decrease adipogenesis. However, miR-17-5p and miR-106a are directly targeting BMP2, which has a reverse effect on the differentiation of hADSC. Downregulation of BMP2 through RNA interference suppressed osteogenesis and increased adipogenic differentiation [22]. By the application of a dual-luciferase assay, Chen et al. identified RhoA and 'mitogen-activated protein kinase 1' (ERK1) as direct targets of miR-125a-3p and miR-483-5p. Downregulation of these microRNAs in hADSC resulted in a decreased ERK1/2 phosphorylation in the nucleus in subcutaneous adipose tissue of patients with multiple symmetric lipomatosis.

Furthermore, miR-125a-3p and miR-483-5p promote the de novo formation of adipose tissue in nude mice [36]. Mei et al. demonstrated that through regulating the ERK-MAPK pathway, the only active signaling during adipogenic, osteogenic and chondrogenic differentiation, miR-21 stimulates MSC differentiation on an early stage. In this context, the expression of the marker gene for adipogenesis, $\operatorname{PPAR} \gamma$, and the marker gene for osteogenesis, Cbfa-1, were both increased after transfection of MSC with miR-21 mimics, while miR-21 inhibition resulted in a reduced expression level of both genes [23]. MiR-26b knockdown inhibits the accumulation of lipid droplets in adipogenic differentiation in human preadipocytes. Furthermore, the expression levels of PPAR $\gamma, \mathrm{AP} 2, \mathrm{C} / \mathrm{EBP} \alpha$ and hormone-sensitive lipase (HSL) are reduced in knockdown cells towards untreated cells [24]. Moreover, PTEN was identified as a direct target of miR-26a [25,57]. Zhang and colleagues identified tumor necrosis factor $(\mathrm{TNF} \alpha)$ by use of bioinformatical methods as an indirect target of miR-29b. Via specificity protein 1 (SP-1), it acts as enhancer of the adipogenic differentiation. Thereby, lipid accumulation in hADSC is promoted and the mitotic clonal expansion is inhibited [29]. Further well-studied microRNAs, which promote adipogenic differentiation, are the miR-30 family. It directly targets 'plasminogen activator inhibitor' (PAI-1) and 'anaplastic lymphoma kinase' (ALK2) in hMADS and enforces adipocyte marker gene induction. Interestingly, only the silencing of both genes leads to a pro-adipogenic effect of miR-30c, while silencing of one target has no effect on adipogenesis [31]. Additionally, Zaragosi 
and colleagues identified miR-30 with the help of gain and loss of function studies as enhancer of adipogenesis. Via 'Runt- related transcription factor' (RUNX2), also known as Cbfa-1, miR-30 family acts as a key regulator balancing adipogenesis and osteogenesis [30]. The miR-320 family has a similar effect [49]. Recent studies investigated 'lysine-specific demethylase 6A' (KDM6A) as a target of miR-199a-3p which regulates WNT signaling downstream [47]. The promoting effect of mir-199a-3p could be validated in 3T3-L1 cells [62]. Wang et al. identified mir-342-3p as a further powerful promoter of the adipogenic differentiation. Both in humans and in obese mice, it is upregulated during adipogenesis. The inhibition of miR-342-3p results in a decreased expression of adipogenic markers like PPAR $\gamma, \mathrm{C} / \mathrm{EBP} \alpha, \mathrm{FABP} 4$, and LPL. By the use of luciferase assays, CtBP2 was confirmed as a direct target of miR-342-3p [51].

\section{Androgen-Regulated microRNAs (AndroMiRs)}

Although several tissues have been shown to be androgen-sensitive, the utmost studies performed on androgen-regulated microRNAs (AndroMiRs) are from prostate carcinoma (PCa) or breast carcinoma (BCa) and the respective cell lines, potentially resulting in a bias, as these model systems represent pathological tissues and therefore are not necessarily reflecting the miRNome of their corresponding somatic counterparts. With regard to the existing literature on identified AndroMiRs, this fact has to be considered. Thus, in many cases, studies on the androgen-regulation of these proposed AndroMiRs in somatic tissues are still warranted.

As the first AndroMiR, miR-125b was identified in the androgen-sensitive prostate carcinoma cell line LNCaP to be induced by the synthetic androgen R1881 treatment [63]. Furthermore, miR-125b stimulated androgen-independent growth of LNCaP cells, also by targeting of BCL2-antagonist (BAK1) [63]. MiR-125b expression in LNCaP cells was demonstrated to be significantly downregulated by treatment with the AR antagonist bicalutamid, and miR-125b also targeting the AR-repressor complex protein (NCOR2) [64]. An induction of miR-125b expression in LNCaP cells after stimulation with DHT was also observed [65]. Concordantly, Sun and colleagues reported AR-mediated regulation on the promoter of the miR-99a/let-7c/miR-125b-2 cluster host gene LINC00478, although showing repression of miR-125b in reaction to AR stimulation with R1881. Additionally, the expression of the miR-100/let-7a-2/miR-125b-1 cluster was not affected by androgen stimulation [66]. Also in the breast cancer cell line MDA-MB-453, treatment with the AR-agonist CI-4AS-1 resulted in a significant downregulation of miR-125b and miR-100 and induced the expression of their target gene metalloprotease-13 (MMP13) [67]. In a non-transformed cell system, Sen and colleagues demonstrated induction of miR-125b, but not miR-125a, expression in mouse granulosa cells upon stimulation with testosterone or dihydrotestosterone, while estradiol stimulation exhibited no effect [68].

As one of the most prominent oncogenic microRNAs, miR-21 was early identified to be upregulated by R1881 treatment in the androgen-sensitive PCa cell lines LNCaP and LAPC-4 [69]. Additionally, the same group intensely studied the miR-21 promoter region by bioinformatics and furthermore demonstrated AR recruitment to an ARE in this promoter region by chromatin immunoprecipitation (ChIP) $[69,70]$. Concordantly, Mishra and colleagues described the downregulation of miR-21 in AR-silenced prostate cancer cell lines (22Rv1 and MDA-PCA-2b), resulting in the increased expression of the miR-21 target gene TGFBR2, as well as the formation of a positive AR-miR-21 feedback loop in prostate epithelial cells [71]. Teng and colleagues observed the induction of miR-21 through AR activation by several dihydroepiandrosterone (DHEA) metabolites, among them DHT, by promoter recruitment visualized via ChIP in the hepatocellular carcinoma cell line HepG2 [72]. Contrarily, in the breast cancer cell lines MCF-7 and SK-BR-3 the AR was shown to downregulate miR-21 expression, primarily by recruiting HDAC3 to the miR-21 promoter [73].

Also in LNCaP, the expression of miR-101 was shown to be upregulated following R1881 treatment, while subsequently the expression of its target gene 'enhancer of zeste homolog' (Ezh2) was downregulated [74]. The same relationship could be demonstrated in mouse granulosa cells, where Ezh2 is initially inactivated via phosphorylation mediated by the PI3K/Akt pathway, then Ezh2 
transcript is downregulated via the testosterone-mediated induction of miR-101 expression [75]. In the neuronal cell line SH-SY5Y and the glioblastoma cell line U251, miR-101 was upregulated after testosterone stimulation resulting in the downregulation of CYP2D6 [76]. Guo et al. verified an AR binding site in the promoter region of miR-101 via ChIP, thus linking AR-induced autophagy inhibition in prostate cancer cell lines to miR-101 upregulation [77].

MiR-221 was initially detected as regulator of Dvl2 and being upregulated in an androgen-insensitive LNCaP-AI cell line in comparison to the original LNCaP, while miR-222, miR-21, miR-125b, and miR-101 were also differentially expressed in these cells [78]. Gui and colleagues identified miR-221/222 as AR-repressed gene, showing downregulation of pri-miR-221/222 after androgen stimulated chromatin modification of the miR-221/222 host gene promoter region [79]. In line with these findings are the results of Sun et al., showing the involvement of miR-221/222 in the development of castration-resistant prostate carcinoma [80-83].

MiR-27a was identified as oncomiR in PCa by targeting the AR corepressor Prohibitin (pHB) [84]. Furthermore, for the miR-23a/27a/24-2 cluster it was demonstrated that the AR in PCa cell lines not only induces the transcription by binding to an ARE in the promoter region, but also accelerates the processing of the pri-miR-23a/27a/24-2 cluster [84]. Concordantly, Mo and colleagues showed the upregulation of miR-27a expression (besides miR-133b and miR-19a) by DHT stimulation of LNCaP cells, and proposed 'ATP-binding cassette transporter' (ABCA1) and 'sister chromatid cohesion protein' (PDS5B) as target genes of miR-27a [85]. In castration-resistant PCA, miR-27a was found to be repressed by the PI3K pathway, thereby levering the repression of its target gene MAP2K4 [86]. In the endothelial cell line EA.hy926 as well as in HUVEC, DHT stimulation downregulated miR-27a expression and upregulated expression of its target gene TFPI $\alpha$ [87]. Also, in a mouse model of the polycystic ovary syndrome characterized by androgen excess, DHT facilitates the upregulation of miR-27a in the granulosa cells resulting in a feedback loop by miR-27a targeting the transcription factor Creb1 [88].

MiR-32, as well as miR-148a, was demonstrated to be upregulated in LNCaP cells after stimulation with DHT and to target BTG2 [89]. By siRNA-mediated knockdown of AR in prostate cancer cell lines, miR-32 was found to be upregulated and to enhance NSE activity, thereby promoting neuroendocrine differentiation of the prostate cancer cells [90].

In a Northern blot approach, miR-200c was observed to be differentially expressed between androgen-sensitive and androgen-insensitive PCa cell lines [91]. Furthermore, members of the miR-200 family comprising miR-200a-c were found to be upregulated by R1881 treatment in AR-induced PC-3 cells, with the highest increase of miR-200b expression, resulting in the suppression of proliferation and invasiveness of the prostate carcinoma cells [92]. Furthermore, miR-200a and miR-200b are higher expressed in the androgen-sensitive LNCaP cell line in comparison to androgen-insensitive DU145, and siRNA-mediated silencing of AR in LNCaP leads to a decrease in miR-200a/b and an increase of their target gene 'zinc finger E-box-binding homeobox 2' (ZEB2) [93].

By luciferase reporter assays and ChIP analyses, the miR-1-2 promoter region was shown to be activated by the AR, and miR-1 targeting 'tyrosine-protein kinase' (SRC) in DU145 derived prostate cancer cell lines [94]. Interestingly, the miR-1-2 promoter is also targeted by 'Kruppel like factor 4' (Klf4), which expression itself is induced by the AR [95]. Additionally, androgen-induced miR-1 downregulates TCF7 in prostate cancer cell lines and therefore negatively impacts the Wnt signaling pathway [96]. Another target gene of miR-1, in the context of the transition of PCa from androgen-sensitive to castration-resistant, is ZBTB46 [97].

MiR-375 and miR-141 were initially detected to be upregulated in the serum of patients with castration-resistant prostate carcinoma [98]. In LNCaP cells, significant overexpression of miR-375 and miR-141 was shown after stimulation with DHT for $24 \mathrm{~h}$ [99]. Conversely, Chu and colleagues demonstrated low expression of this microRNA and hypermethylation of the miR-375 promoter in the AR-negative PCa cell lines Du145 and PC-3 [100]. The same effect was observed in differentiating 
SGBS preadipocytes, where testosterone or DHT stimulation led to the downregulation of miR-375 during the differentiation course and upregulation of its target gene ADIPOR2 [54].

Other AndroMiRs include let-7a, b, c [101], let-7d [102], miR-135a [103,104], miR-141 [99,105], members of the miR-17 92 cluster [106,107], miR-216a [108,109], miR-29 family members [110,111] and miR-30 family members [99,112]. Additional proposed androgen-regulated microRNAs-yet not intensively studied—are given in Table 2 .

Table 2. Androgen-regulated microRNAs (AndroMiRs).

\begin{tabular}{|c|c|c|c|c|c|}
\hline microRNA & $\begin{array}{l}\text { Androgen } \\
\text { Regulation }\end{array}$ & Tissue & Cell Line & $\begin{array}{c}\text { Target Gene/ } \\
\text { Signaling Pathway }\end{array}$ & Reference \\
\hline let-7a & $\mathrm{u}$ & BCA & $\begin{array}{l}\text { MCF-7; } \\
\text { MDA-MB-231; } \\
\text { MDA-MB-453 }\end{array}$ & KRAS; CMYC & Lyu et al., 2014 [101] \\
\hline let-7c & $\mathrm{d}$ & PCA & LNCaP & IGFR1 & Sun et al., 2014 [66] \\
\hline let-7d & $\mathrm{u}$ & PCA & $\mathrm{LNCaP}, \mathrm{C} 4-2 \mathrm{~B}$ & PBX3 & Ramberg et al., 2011 [102] \\
\hline $\operatorname{miR}-1$ & $\mathrm{u}$ & PCA & LNCaP & SRC & Liu et al., 2015 [94] \\
\hline miR-1 & $\mathrm{u}$ & PCA & LNCaP & TCF7 & Siu et al., 2017 [96] \\
\hline miR-1 & $\mathrm{u}$ & PCA & LNCaP & ZBTB46 & Chen et al.,2017 [97] \\
\hline $\begin{array}{l}\text { miR-17-92 } \\
\text { cluster }\end{array}$ & $\mathrm{u}$ & PCA & LNCaP; 22Rv1 & ATG7 & Guo et al., 2016 [107] \\
\hline $\begin{array}{l}\text { miR-17-92 } \\
\text { cluster }\end{array}$ & $\mathrm{u}$ & PCA & DUCaP; LNCaP & - & Pasqualini et al., 2015 [106] \\
\hline miR-19a & $\mathrm{u}$ & PCA & LNCaP & $\begin{array}{c}\text { SUZ12; RAB13; } \\
\text { SC4MOL; PSAP; } \\
\text { ABCA1 }\end{array}$ & Mo et al., 2013 [85] \\
\hline miR-21 & $\mathrm{u}$ & PCA & LNCaP; LAPC-4 & - & Ribas et al., 2009 [69] \\
\hline $\operatorname{miR}-21$ & $\mathrm{u}$ & PCA & LNCaP & - & Ribas et al., 2010 [70] \\
\hline $\operatorname{miR}-21$ & $\mathrm{u}$ & $\mathrm{HCC}$ & HepG2 & PDCD4 & Teng et al., 2014 [72] \\
\hline $\operatorname{miR}-21$ & $\mathrm{u}$ & PCA & $\begin{array}{l}\text { BPH-1; 22Rv1; } \\
\text { PC-3 }\end{array}$ & TGFBR2 & Mishra et al., 2014 [71] \\
\hline $\operatorname{miR}-21$ & d & BCA & MCF-7 & - & Casaburi et al., 2016 [73] \\
\hline miR-22 & $\mathrm{u}$ & placenta & JEG-3 & ESR1 & Shao et al., 2017 [113] \\
\hline $\operatorname{miR}-22$ & $\mathrm{u}$ & PCA & DUCaP; LNCaP & LAMC1 & Pasqualini et al., 2015 [106] \\
\hline $\operatorname{miR}-23 b$ & d & $\begin{array}{l}\text { mouse } \\
\text { Sertolicells }\end{array}$ & - & PTEN & Nicholls et al., 2011 [112] \\
\hline $\operatorname{miR}-27 a$ & $\mathrm{u}$ & PCA & LNCaP & PHB & Fletcher et al., 2012 [84] \\
\hline $\operatorname{miR}-27 a$ & $\mathrm{u}$ & PCA & LNCaP & ABCA1; PDS5B & Mo et al., 2013 [85] \\
\hline $\operatorname{miR}-27 a$ & $\mathrm{u}$ & PCA & $\begin{array}{l}\text { LNCaP, 22Rv1; } \\
\text { Du145; } \\
\text { PC3 }\end{array}$ & MAP2K4 & Wan et al., 2016 [86] \\
\hline $\mathrm{miR}-27 \mathrm{a} / \mathrm{b}$ & d & $\begin{array}{l}\text { endothelial cell } \\
\text { lines }\end{array}$ & EA.hy926; HUVEC & TFPI $\alpha$ & B Arroyo et al., 2017 [87] \\
\hline miR-29a & $\mathrm{u}$ & PCA & DUCaP; LNCaP & Mcl-1 & Pasqualini et al., 2015 [106] \\
\hline $\mathrm{miR}-29 \mathrm{a} / \mathrm{b}$ & d & epididymis & PC-1 & AR, IGF1 & Ma et al., 2013 [110] \\
\hline miR-29b & $\mathrm{u}$ & PCA & LNCaP; BicR & TET2 & Takayama et al., 2015 [111] \\
\hline miR-30d & $\mathrm{d}$ & Sertoli cells & - & - & Nicholls et al., 2011 [112] \\
\hline miR-32 & $\mathrm{u}$ & PCA & $\begin{array}{c}\text { 22Rv1; } \\
\text { LNCaP;RWPE1 }\end{array}$ & NSE & Dang et al., 2015 [7] \\
\hline miR-32 & $\mathrm{u}$ & PCA & LNCaP & BTG2 & Jalava et al., 2012 [89] \\
\hline miR-99a & $\mathrm{d}$ & PCA & LNCaP & IGFR1 & Sun et al., 2014 [66] \\
\hline miR-100 & $\mathrm{d}$ & BCA & MDA-MB-453 & MMP13 & Ahram et al., 2017 [67] \\
\hline miR-101 & $\mathrm{u}$ & PCA & LNCaP & Ezh2 & Cao et al., 2010 [74] \\
\hline miR-101 & $\mathrm{u}$ & PCA & LNCaP & - & Guo et al., 2015 [77] \\
\hline miR-101 & $\mathrm{u}$ & granulosa cells & $\begin{array}{c}\text { primary mouse } \\
\text { GCs; } \\
\text { KGN }\end{array}$ & Ezh2 & Ma et al., 2017 [75] \\
\hline miR-101 & $\mathrm{u}$ & neuronal cells & SH-SY5Y; U251 & CYP2D6 & Li et al., 2015 [76] \\
\hline miR-124 & $\mathrm{u}$ & PCA & PC3; LNCaP & AR & Chu et al., 2015 [114] \\
\hline $\operatorname{miR}-125 b$ & $\mathrm{u}$ & PCA & LNCaP; cds1 & Bak1 & Shi et al., 2007 [63] \\
\hline miR-125b & $\mathrm{u}$ & PCA & $\mathrm{LNCaP}$ & NCOR2 & Yang et al., 2012 [64] \\
\hline miR-125b & $\mathrm{d}$ & PCA & LNCaP & - & Sun et al., 2014 [66] \\
\hline miR-125b & $\mathrm{u}$ & PCA & LNCaP & - & Yang et al., 2015 [65] \\
\hline miR-125b & d & BCA & MDA-MB-453 & MMP13 & Ahram et al., 2017 [67] \\
\hline miR-128-2 & $\mathrm{u}$ & neuronal cells & SH-SY5Y; U251 & CYP2D6 & Li et al., 2015 [76] \\
\hline miR-133b & $\mathrm{u}$ & PCA & LNCaP & $\begin{array}{l}\text { CDC2L5; PTPRK; } \\
\text { RB1CC1; CPNE3 }\end{array}$ & Mo et al., 2013 [85] \\
\hline miR-133b & $\mathrm{u}$ & PCA & LNCaP & - & Yang et al., 2015 [65] \\
\hline miR-135a & $\mathrm{u}$ & PCA & LNCaP; PC-3 & ROCK1, ROCK2 & Kroiss et al., 2015 [84] \\
\hline miR-135a & $\mathrm{u}$ & PCA & LNCaP & MMP11, RBAK & Wan et al., 2016 [104] \\
\hline
\end{tabular}


Table 2. Cont.

\begin{tabular}{|c|c|c|c|c|c|}
\hline microRNA & $\begin{array}{l}\text { Androgen } \\
\text { Regulation }\end{array}$ & Tissue & Cell Line & $\begin{array}{c}\text { Target Gene/ } \\
\text { Signaling Pathway }\end{array}$ & Reference \\
\hline $\operatorname{miR}-137$ & $\mathrm{u}$ & PCA & LNCaP & $\begin{array}{l}\text { KDM2A, KDM4A; } \\
\text { KDM5B; KDM7A; } \\
\text { MED1 }\end{array}$ & Nilsson et al., 2015 [115] \\
\hline miR-141 & $\mathrm{u}$ & PCA & LNCaP, VCaP & - & Waltering et al., 2011 [105] \\
\hline miR-141 & $\mathrm{u}$ & PCA & LNCaP & - & Tiryakioglu et al., 2013 [99] \\
\hline $\operatorname{miR}-141$ & $\mathrm{u}$ & PCA & tissue & - & Nguyen et al., 2013 [98] \\
\hline miR-141 & $\mathrm{u}$ & PCA & LNCaP & - & Gezer et al., 2015 [116] \\
\hline miR-145 & $\mathrm{d}$ & $\mathrm{RCC}$ & $\begin{array}{c}\text { ACHN; SCRC-2; } \\
\text { SW-839 }\end{array}$ & $\mathrm{HIF} 2 \alpha$ & Chen et al., 2015 [117] \\
\hline miR-148a & $\mathrm{u}$ & PCA & LNCaP & CAND1 & Murata et al., 2011 [118] \\
\hline miR-148a & $\mathrm{u}$ & PCA & LNCaP & - & Jalava et al., 2012 [89] \\
\hline miR-182-5p & $\mathrm{u}$ & PCA & LNCaP & ARRDC3 & Yao et al., 2016 [119] \\
\hline miR-185-5p & $\mathrm{u}$ & RCC & SW839 & $\begin{array}{l}\text { VEGF-c; } \\
\text { HIF2 } \alpha\end{array}$ & Huang et al., 2017 [120] \\
\hline miR-190a & $\mathrm{d}$ & PCA & LNCaP & AR; YB1 & Xu et al., 2015 [121] \\
\hline miR-193a-3p & $\mathrm{u}$ & PCA & $\mathrm{LNCaP} ; \mathrm{C} 4-2 \mathrm{~B}$ & AJUBA & Jia et al., 2017 [122] \\
\hline $\mathrm{miR}-200 \mathrm{a} / \mathrm{b}$ & $\mathrm{u}$ & PCA & $\begin{array}{l}\text { LNCaP; PC-3; } \\
\text { Du145 }\end{array}$ & ZEB2 & Jacob et al., 2014 [93] \\
\hline miR-200a-c & $\mathrm{u}$ & PCA & PC-3-AR & - & Williams et al., 2013 [92] \\
\hline miR-203 & $\mathrm{u}$ & PCA & $\mathrm{LNCaP} ; 22 \mathrm{Rv} 1$ & SRC & Siu et al., 2016 [95] \\
\hline miR-204 & $\mathrm{d}$ & PCA & LNCaP, 22Rv1 & XRN1 & Ding et al., 2015 [123] \\
\hline $\mathrm{miR}-216 \mathrm{a}$ & $\mathrm{u}$ & $\mathrm{HCC}$ & tissue & TSLC1 & Chen et al., 2012 [108] \\
\hline miR-216a & $\mathrm{u}$ & PCA & LNCaP & - & Miyazaki et al., 2015 [109] \\
\hline $\operatorname{miR}-221 / 222$ & $\mathrm{~d}$ & PCA & $\mathrm{LNCaP} ; \mathrm{C} 4-2 \mathrm{~B}$ & - & Gui et al., 2017 [79] \\
\hline $\operatorname{miR}-363$ & $\mathrm{u}$ & BCA & MCF-7 & IQWD1 & Nakano et al., 2013 [124] \\
\hline $\operatorname{miR}-375$ & $\mathrm{u}$ & PCA & $\begin{array}{c}\text { LNCaP; C4-2; } \\
\text { 22Rv1; } \\
\text { PC-3; Du145 }\end{array}$ & - & Chu et al., 2014 [100] \\
\hline $\operatorname{miR}-375$ & $\mathrm{~d}$ & hMSC & SGBS & ADIPOR2 & Kraus et al., 2015 [54] \\
\hline $\operatorname{miR}-375$ & $\mathrm{u}$ & PCA & LNCaP & - & Tiryakioglu et al., 2013 [99] \\
\hline $\operatorname{miR}-375$ & $\mathrm{u}$ & PCA & tissue & - & Nguyen et al., 2013 [98] \\
\hline $\operatorname{miR}-421$ & d & PCA & $\begin{array}{c}\text { LNCaP; 22Rv1; } \\
\text { Du145; } \\
\text { PC-3 }\end{array}$ & $\begin{array}{l}\text { NRAS, PRAME, } \\
\text { CUL4B, PFKMB2 }\end{array}$ & Meng et al., 2016 [125] \\
\hline miR-471-5p & $\mathrm{u}$ & Sertoli cells & primary cells & LAP & $\begin{array}{c}\text { Panneerdoss et al.,2017 } \\
{[126,127]}\end{array}$ \\
\hline miR-690 & $\mathrm{d}$ & Sertoli cells & - & - & Nicholls et al., 2011 [112] \\
\hline miR-2909 & $\mathrm{u}$ & PCA & LNCaP & TGFBR2 & Ayub et al., 2017 [128] \\
\hline $\mathrm{miR}-4496$ & $\mathrm{u}$ & PCA & LNCaP & $\beta$-Catenin & Wang et al., 2018 [129] \\
\hline
\end{tabular}

Interestingly, Panneerdoss and colleagues studied testosterone-specific microRNA signatures in mouse sertoli cells, identifying two X-linked microRNA clusters (Cluster 1: miR-743a, miR-471, miR-741, miR-463, miR-880, miR-878, and miR-871. Cluster 2: miR-201 and miR-547) highly induced by testosterone [126,127]. Although the AR is regulating the expression of many microRNAs, AR translation is also repressed by several microRNAs (an actual overview is given in Table S3), therefore, adding an additional regulative layer to the interplay between these two factors in differentiation processes.

\section{AndroMiRs Putatively Involved in Adipogenesis}

Comparing the androgen-regulated microRNAs (AndroMiRs) to the adipogenesis-related microRNAs (AdipoMiRs), several overlapping candidates can be extracted from the existing literature. In Figure 2, putative candidates for microRNAs involved in the androgen-mediated inhibition of the adipogenesis are given. 


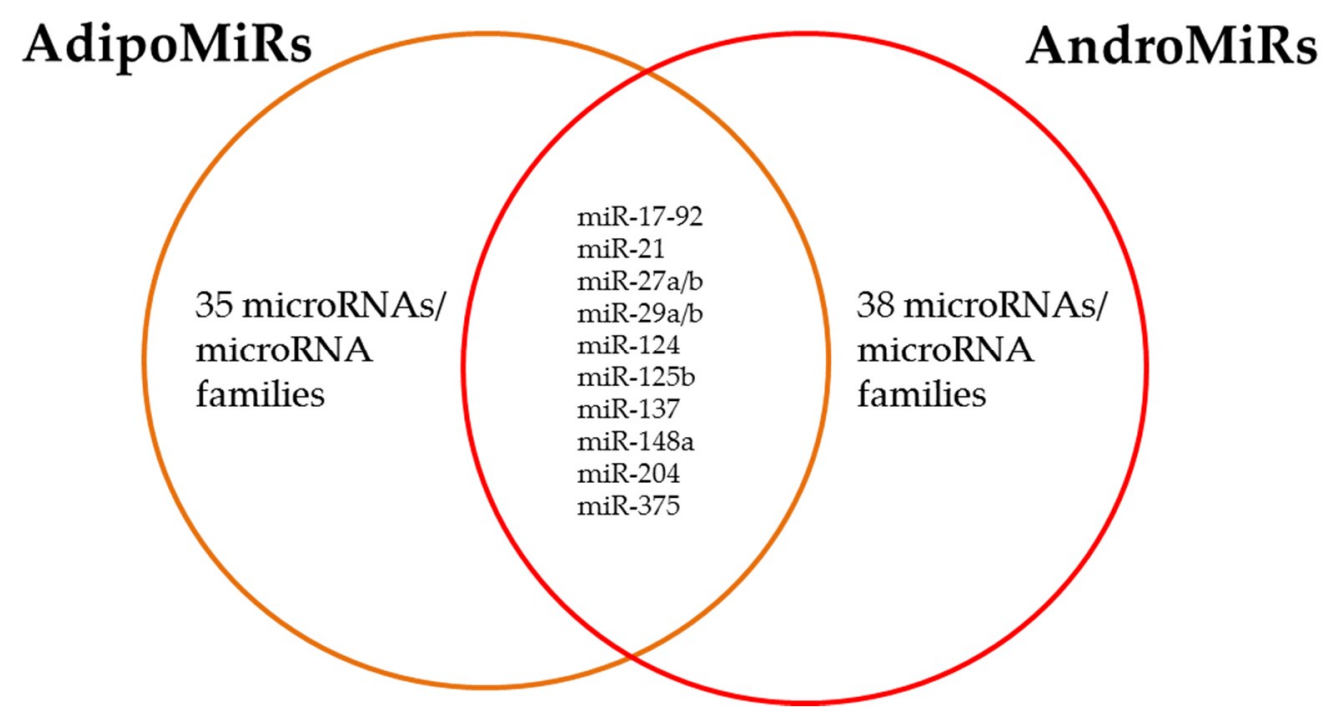

Figure 2. Putative overlap of microRNAs identified as adipogenesis-related or androgen-regulated so far.

MiR-17-5p/miR-106a was shown to determine lineage commitment in early hMSC differentiation, wherein the upregulation was of both microRNAs suppressed BMP2 expression and therefore shifting the MSC fate towards adipogenesis [22]. However, in PCa cell lines androgens triggered the upregulation of the miR-17-92 cluster [106,107], therefore, analysis of the regulation in somatic tissues remains crucial for the determination of the role of this cluster in differentiation processes. MiR-21 upregulation increased the potential of adipogenic and osteogenic differentiation of hMSCs via modulation of the ERK-MAPK4 pathway [23], therefore, being no adipogenesis-specific modulator. In line with this fact, the androgen-induced upregulation of miR-21 observed in several studies [69-72] may point towards a general role of this microRNA in differentiation initiation, rather than driving a special lineage commitment. Regarding the miR-27a/b family, there is still a discrepancy in the role and regulation of the individual family members. In androgen-responsive PCa cell lines, mainly the induction of miR-27a (located on chromosome 19) is described [84-86]. Only in one study an androgen-responsiveness of miR-27b (located on chromosome 9) in endothelial cells was observed [87]. Nonetheless, in hMSCs, it is mainly miR-27b regulating adipogenesis by targeting the key adipogenic transcription factor PPAR $\gamma[26,27]$. However, there are several reports from mouse pre-adipocytes verifying the assumption that miR-27a exhibits the same role as miR-27b by repressing adipogenic differentiation of mouse 3T3-L1 cells [61,130,131].

A similar situation is given for the miR-29 family, where miR-29b is involved in adipogenesis of human mesenchymal stem cells [28,29], while both miR-29a and miR-29b are androgen-regulated in PCa cell lines, but also in epididymal cells $[106,110,111]$. When comparing in vitro differentiated osteoblasts, adipocytes, and chondroblasts to their originating mesenchymal stem cells, Laine et al. found miR-124 to be exclusively expressed in adipocytes and to suppress proliferation of hMSCs [35]. Qadir and colleagues concordantly detected that miR-124 exerts a pro-adipogenic effect on 3T3-L1 mouse preadipocytes [132]. In PCa cell lines, the tumor-suppressive miR-124 and the AR formed a positive feedback loop [114]. As one of the most prominent androgen-regulated microRNAs [63-67], miR-125b is still scarcely studied in terms of adipogenesis. However, it was shown that miR- $125 \mathrm{~b}$ is overexpressed during human SGBS preadipocyte differentiation, though experimental overexpression of miR-125b by mimics inhibited the adipogenic differentiation [37].

These observations point towards a strictly balanced regulatory network including miR-125b, which can be shaped via androgen-induced upregulation of this microRNA towards the inhibition of adipogenesis. MiR-137 is induced via androgen stimulation in PCa cell lines, though progressive promoter methylation is detected from normal prostate tissue to androgen-insensitive PCa cell 
lines [115]. In line with this finding, the overexpression of miR-137 inhibits hADSC proliferation and differentiation [39]. MiR-148a was found to be CREB-induced upon the adipogenic differentiation of hMSCs and promoting hMSC adipogenesis commitment by targeting the Wnt pathway effector Wnt-1 [41]. In the androgen-responsive PCa cell line LNCaP, miR-148a expression is also induced by androgens, resulting in increased cell proliferation $[89,118]$. The tumor-suppressive miR-204 is downregulated upon androgen stimulation in PCa cell lines [123]. In line with the androgen-mediated inhibition of the adipogenesis, miR-204 is upregulated in differentiating hADSCs and inhibits the activation of the Wnt pathway, therefore, supporting the initiation of differentiation [48]. Lastly, miR-375 was in several studies shown to be sensitive to androgen regulation [54,98-100], although in PCa cell lines the AR triggers upregulation of miR-375, while in differentiating hMSCs and SGBS preadipocytes miR-375 is downregulated upon androgen stimulation. However, Chu and colleagues demonstrated the hypermethylation of the miR-375 promoter region in androgen-insensitive cell lines, therefore, giving a possible explanation for this different reaction of miR-375 to androgen stimulation [100]. Furthermore, the upregulation of miR-375 was demonstrated during adipogenesis [54], therefore making this the first AndroMiR to be experimentally revealed in the androgen-mediated inhibition of adipogenesis.

Finally, one has to bear in mind, that in most cases the androgen-regulation of a given microRNA was analyzed and verified in tissues or cell lines completely different from the tissues or cell lines used for the studies on the involvement of this microRNA in adipogenesis. Therefore, the connections drawn in this chapter are literature-based, but in most cases still speculative, and should be experimentally verified for a realistic assessment of the androgen-regulated miRNome in the inhibition of adipogenesis.

\section{Conclusions}

While over 30 microRNAs/microRNA families have been described to be involved in the regulation of adipogenesis of human mesenchymal stem cells and pre-adipocytes, and over 30 microRNAs/microRNA families are known to be regulated in their expression by the androgen receptor, knowledge about the AndroMiRs involved in the regulation of the adipogenesis is still scarce. Therefore, based on this review, further experimental studies on the interplay between the AR-mediated miRNome regulation and the inhibition of adipogenesis are needed and also promising, especially in the light of the growing obesity epidemics and the well-known clinical effects of testosterone treatment on reducing adipose tissue in hypogonadal men [133,134].

Supplementary Materials: Supplementary materials can be found at http://www.mdpi.com/1422-0067/20/22/ 5767/s1, Table S1: Adipogenesis-regulating microRNAs in mouse, Table S2: Adipogenesis-regulating microRNAs in other species, Table S3: microRNAs regulating AR expression.

Author Contributions: Conceptualization, T.G. and H.M.B.; investigation, J.J.; writing-original draft preparation, T.G. and J.J.; writing—review and editing, T.G. and H.M.B.; visualization, T.G.; supervision, H.M.B.; funding acquisition, T.G. and H.M.B. All authors read and approved the final version of the article.

Funding: This study was in part-financed by a DFG (German research foundation) grant (GR-4469/1) to Thomas Greither and Hermann M. Behre. Furthermore, we acknowledge the financial support within the funding program Open Access Publishing by the German Research Foundation (DFG).

Conflicts of Interest: The authors declare no conflict of interest. The funders had no role in the design of the study; in the collection, analyses, or interpretation of data; in the writing of the manuscript, or in the decision to publish the results.

\section{References}

1. Heinlein, C.A.; Chang, C. Androgen Receptor (AR) Coregulators: An Overview. Endocr. Rev. 2002, 23, 175-200. [CrossRef] [PubMed]

2. Lee, D.K.; Chang, C. Molecular communication between androgen receptor and general transcription machinery. J. Steroid Biochem. Mol. Biol. 2003, 84, 41-49. [CrossRef]

3. Knoll, M.; Lodish, H.F.; Sun, L. Long non-coding RNAs as regulators of the endocrine system. Nat. Rev. Endocrinol. 2015, 11, 151-160. [CrossRef] [PubMed] 
4. Ceder, Y. Non-coding RNAs in Prostate Cancer: From Discovery to Clinical Applications. Adv. Exp. Med. Biol. 2016, 886, 155-170.

5. Chua, F.Y.; Adams, B.D. Androgen receptor and miR-206 regulation in prostate cancer. Transcription 2017, 8 , 313-327. [CrossRef]

6. Pelletier, G. Localization of androgen and estrogen receptors in rat and primate tissues. Histol. Histopathol. 2000, 15, 1261-1270.

7. McEwan, I.J. Androgen receptor modulators: A marriage of chemistry and biology. Futur. Med. Chem. 2013, 5, 1109-1120. [CrossRef]

8. Blouin, K.; Boivin, A.; Tchernof, A. Androgens and body fat distribution. J. Steroid Biochem. Mol. Biol. 2008, 108, 272-280. [CrossRef]

9. Dieudonné, M.N.; Pecquery, R.; Boumediene, A.; Leneveu, M.C.; Giudicelli, Y. Androgen receptors in human preadipocytes and adipocytes: Regional specificities and regulation by sex steroids. Am. J. Physiol. Content 1998, 274, C1645-C1652. [CrossRef]

10. Singh, R.; Artaza, J.N.; Taylor, W.E.; Gonzalez-Cadavid, N.F.; Bhasin, S. Androgens Stimulate Myogenic Differentiation and Inhibit Adipogenesis in C3H 10T1/2 Pluripotent Cells through an Androgen Receptor-Mediated Pathway. Endocrinology 2003, 144, 5081-5088. [CrossRef]

11. Singh, R.; Artaza, J.N.; Taylor, W.E.; Braga, M.; Yuan, X.; Gonzalez-Cadavid, N.F.; Bhasin, S. Testosterone inhibits adipogenic differentiation in 3T3-L1 cells: Nuclear translocation of androgen receptor complex with beta-catenin and T-cell factor 4 may bypass canonical Wnt signaling to down-regulate adipogenic transcription factors. Endocrinology 2006, 147, 141-154. [CrossRef] [PubMed]

12. Gupta, V.; Bhasin, S.; Guo, W.; Singh, R.; Miki, R.; Chauhan, P.; Choong, K.; Tchkonia, T.; Lebrasseur, N.K.; Flanagan, J.N.; et al. Effects of dihydrotestosterone on differentiation and proliferation of human mesenchymal stem cells and preadipocytes. Mol. Cell. Endocrinol. 2008, 296, 32-40. [CrossRef] [PubMed]

13. Benvenuti, S.; Cellai, I.; Luciani, P.; Deledda, C.; Saccardi, R.; Mazzanti, B.; Dal Pozzo, S.; Serio, M.; Peri, A. Androgens and estrogens prevent rosiglitazone-induced adipogenesis in human mesenchymal stem cells. J. Endocrinol. Investig. 2012, 35, 365-371.

14. Blouin, K.; Nadeau, M.; Perreault, M.; Veilleux, A.; Drolet, R.; Marceau, P.; Mailloux, J.; Luu-The, V.; Tchernof, A. Effects of androgens on adipocyte differentiation and adipose tissue explant metabolism in men and women. Clin. Endocrinol. 2010, 72, 176-188. [CrossRef]

15. Lefterova, M.I.; Lazar, M.A. New developments in adipogenesis. Trends Endocrinol. Metab. TEM 2009, 20, 107-114. [CrossRef]

16. Takada, I.; Kouzmenko, A.P.; Kato, S. Wnt and PPARgamma signaling in osteoblastogenesis and adipogenesis. Nat. Rev. Rheumatol. 2009, 5, 442-447. [CrossRef]

17. Ross, S.E. Inhibition of Adipogenesis by Wnt Signaling. Science 2000, 289, 950-953. [CrossRef]

18. Bennett, C.N.; Ross, S.E.; Longo, K.A.; Bajnok, L.; Hemati, N.; Johnson, K.W.; Harrison, S.D.; MacDougald, O. Regulation of Wnt Signaling during Adipogenesis. J. Biol. Chem. 2002, 277, 30998-31004. [CrossRef]

19. Chen, L.; Hou, J.; Ye, L.; Chen, Y.; Cui, J.; Tian, W.; Li, C.; Liu, L. MicroRNA-143 Regulates Adipogenesis by Modulating the MAP2K5-ERK5 Signaling. Sci. Rep. 2014, 4, 3819. [CrossRef]

20. Bartel, D.P. MicroRNAs. Cell 2004, 116, 281-297. [CrossRef]

21. Li, H.; Fan, J.; Fan, L.; Li, T.; Yang, Y.; Xu, H.; Deng, L.; Li, J.; Li, T.; Weng, X.; et al. MiRNA-10b Reciprocally Stimulates Osteogenesis and Inhibits Adipogenesis Partly through the TGF- $\beta /$ SMAD2 Signaling Pathway. Aging Dis. 2018, 9, 1058-1073. [CrossRef] [PubMed]

22. Li, H.; Li, T.; Wang, S.; Wei, J.; Fan, J.; Li, J.; Han, Q.; Liao, L.; Shao, C.; Zhao, R.C. miR-17-5p and miR-106a are involved in the balance between osteogenic and adipogenic differentiation of adipose-derived mesenchymal stem cells. Stem Cell Res. 2013, 10, 313-324. [CrossRef] [PubMed]

23. Mei, Y.; Bian, C.; Li, J.; Du, Z.; Zhou, H.; Yang, Z.; Zhao, R.C. miR-21 modulates the ERK-MAPK signaling pathway by regulating SPRY2 expression during human mesenchymal stem cell differentiation. J. Cell. Biochem. 2013, 114, 1374-1384. [CrossRef] [PubMed]

24. Song, G.; Xu, G.; Ji, C.; Shi, C.; Shen, Y.; Chen, L.; Zhu, L.; Yang, L.; Zhao, Y.; Guo, X. The role of microRNA-26b in human adipocyte differentiation and proliferation. Gene 2014, 533, 481-487. [CrossRef] [PubMed] 
25. Trohatou, O.; Zagoura, D.; Orfanos, N.K.; Pappa, K.I.; Marinos, E.; Anagnou, N.P.; Roubelakis, M.G. miR-26a Mediates Adipogenesis of Amniotic Fluid Mesenchymal Stem/Stromal Cells via PTEN, Cyclin E1, and CDK6. Stem Cells Dev. 2017, 26, 482-494. [CrossRef]

26. Karbiener, M.; Fischer, C.; Nowitsch, S.; Opriessnig, P.; Papak, C.; Ailhaud, G.; Dani, C.; Amri, E.-Z.; Scheideler, M. microRNA miR-27b impairs human adipocyte differentiation and targets PPARgamma. Biochem. Biophys. Res. Commun. 2009, 390, 247-251. [CrossRef]

27. Hu, X.; Tang, J.; Hu, X.; Bao, P.; Pan, J.; Chen, Z.; Xian, J. MiR-27b Impairs Adipocyte Differentiation of Human Adipose Tissue-Derived Mesenchymal Stem Cells by Targeting LPL. Cell. Physiol. Biochem. 2018, 47, 545-555. [CrossRef]

28. Beezhold, K.; Klei, L.R.; Barchowsky, A. Regulation of cyclin D1 by arsenic and microRNA inhibits adipogenesis. Toxicol. letters 2017, 265, 147-155. [CrossRef]

29. Zhang, X.-M.; Wang, L.-H.; Su, D.-J.; Zhu, D.; Li, Q.-M.; Chi, M.-H. MicroRNA-29b promotes the adipogenic differentiation of human adipose tissue-derived stromal cells. Obesity 2016, 24, 1097-1105. [CrossRef]

30. Zaragosi, L.-E.; Wdziekonski, B.; Le Brigand, K.; Villageois, P.; Mari, B.; Waldmann, R.; Dani, C.; Barbry, P. Small RNA sequencing reveals miR-642a-3p as a novel adipocyte-specific microRNA and miR-30 as a key regulator of human adipogenesis. Genome Biol. 2011, 12, R64. [CrossRef]

31. Karbiener, M.; Neuhold, C.; Opriessnig, P.; Prokesch, A.; Bogner-Strauss, J.G.; Scheideler, M. MicroRNA-30c promotes human adipocyte differentiation and co-represses PAI-1 and ALK2. RNA Biol. 2011, 8, 850-860. [CrossRef] [PubMed]

32. Liu, Y.; Wang, Y.; He, X.; Zhang, S.; Wang, K.; Wu, H.; Chen, L. LncRNA TINCR/miR-31-5p/C/EBP- $\alpha$ feedback loop modulates the adipogenic differentiation process in human adipose tissue-derived mesenchymal stem cells. Stem Cell Res. 2018, 32, 35-42. [CrossRef] [PubMed]

33. Woeller, C.F.; Flores, E.L.; Pollock, S.J.; Phipps, R.P. Editor's Highlight: Thy1 (CD90) Expression is Reduced by the Environmental Chemical Tetrabromobisphenol-A to Promote Adipogenesis Through Induction of microRNA-103. Toxicol. Sci. 2017, 157, 305-319. [CrossRef] [PubMed]

34. Ahonen, M.A.; Haridas, P.N.; Mysore, R.; Wabitsch, M.; Fischer-Posovszky, P.; Olkkonen, V.M. miR-107 inhibits CDK6 expression, differentiation, and lipid storage in human adipocytes. Mol. Cell. Endocrinol. 2019, 479, 110-116. [CrossRef] [PubMed]

35. Laine, S.K.; Alm, J.J.; Virtanen, S.P.; Aro, H.T.; Laitala-Leinonen, T.K.; Laitala-Leinonen, T.K. MicroRNAs miR-96, miR-124, and miR-199a regulate gene expression in human bone marrow-derived mesenchymal stem cells. J. Cell. Biochem. 2012, 113, 2687-2695. [CrossRef]

36. Chen, K.; He, H.; Xie, Y.; Zhao, L.; Zhao, S.; Wan, X.; Yang, W.; Mo, Z. miR-125a-3p and miR-483-5p promote adipogenesis via suppressing the RhoA/ROCK1/ERK1/2 pathway in multiple symmetric lipomatosis. Sci. Rep. 2015, 5, 11909. [CrossRef]

37. Rockstroh, D.; Löffler, D.; Kiess, W.; Landgraf, K.; Körner, A. Regulation of human adipogenesis by miR125b-5p. Adipocyte 2016, 5, 283-297. [CrossRef]

38. Lee, E.K.; Lee, M.J.; Abdelmohsen, K.; Kim, W.; Kim, M.M.; Srikantan, S.; Martindale, J.L.; Hutchison, E.R.; Kim, H.H.; Marasa, B.S.; et al. miR-130 suppresses adipogenesis by inhibiting peroxisome proliferator-activated receptor gamma expression. Mol. Cell. Biol. 2011, 31, 626-638. [CrossRef]

39. Shin, K.K.; Kim, Y.S.; Kim, J.Y.; Bae, Y.C.; Jung, J.S. miR-137 Controls Proliferation and Differentiation of Human Adipose Tissue Stromal Cells. Cell. Physiol. Biochem. 2014, 33, 758-768. [CrossRef]

40. Li, Z.; Jin, C.; Chen, S.; Zheng, Y.; Huang, Y.; Jia, L.; Ge, W.; Zhou, Y. Long non-coding RNA MEG3 inhibits adipogenesis and promotes osteogenesis of human adipose-derived mesenchymal stem cells via miR-140-5p. Mol. Cell. Biochem. 2017, 433, 51-60. [CrossRef]

41. Shi, C.; Zhang, M.; Tong, M.; Yang, L.; Pang, L.; Chen, L.; Xu, G.; Chi, X.; Hong, Q.; Ni, Y.; et al. miR-148a is Associated with Obesity and Modulates Adipocyte Differentiation of Mesenchymal Stem Cells through Wnt Signaling. Sci. Rep. 2015, 5, 9930. [CrossRef] [PubMed]

42. Li, Y.; Yang, F.; Gao, M.; Gong, R.; Jin, M.; Liu, T.; Sun, Y.; Fu, Y.; Huang, Q.; Zhang, W.; et al. miR-149-3p Regulates the Switch between Adipogenic and Osteogenic Differentiation of BMSCs by Targeting FTO. Mol. Ther.-Nucleic Acids 2019, 17, 590-600. [CrossRef] [PubMed] 
43. Skårn, M.; Namløs, H.M.; Noordhuis, P.; Wang, M.-Y.; Meza-Zepeda, L.A.; Myklebost, O. Adipocyte Differentiation of Human Bone Marrow-Derived Stromal Cells Is Modulated by MicroRNA-155, MicroRNA-221, and MicroRNA-222. Stem Cells Dev. 2012, 21, 873-883. [CrossRef] [PubMed]

44. Mysore, R.; Zhou, Y.; Sädevirta, S.; Savolainen-Peltonen, H.; Nidhina Haridas, P.A.; Soronen, J.; Leivonen, M.; Sarin, A.-P.; Fischer-Posovszky, P.; Wabitsch, M.; et al. MicroRNA-192* impairs adipocyte triglyceride storage. Biochim. Biophys. Acta 2016, 1861, 342-351. [CrossRef] [PubMed]

45. Mazzu, Y.Z.; Hu, Y.; Soni, R.K.; Mojica, K.M.; Qin, L.-X.; Agius, P.; Waxman, Z.M.; Mihailovic, A.; Socci, N.D.; Hendrickson, R.C.; et al. miR-193b-Regulated Signaling Networks Serve as Tumor Suppressors in Liposarcoma and Promote Adipogenesis in Adipose-Derived Stem Cells. Cancer Res. 2017, 77, 5728-5740. [CrossRef]

46. Jeong, B.-C.; Kang, I.-H.; Hwang, Y.-C.; Kim, S.-H.; Koh, J.-T. MicroRNA-194 reciprocally stimulates osteogenesis and inhibits adipogenesis via regulating COUP-TFII expression. Cell Death Dis. 2014, 5, e1532. [CrossRef] [PubMed]

47. Shuai, Y.; Yang, R.; Mu, R.; Yu, Y.; Rong, L.; Jin, L. MiR-199a-3p mediates the adipogenic differentiation of bone marrow-derived mesenchymal stem cells by regulating KDM6A/WNT signaling. Life Sci. 2019, 220, 84-91. [CrossRef]

48. He, H.; Chen, K.; Wang, F.; Zhao, L.; Wan, X.; Wang, L.; Mo, Z. miR-204-5p promotes the adipogenic differentiation of human adipose-derived mesenchymal stem cells by modulating DVL3 expression and suppressing Wnt/ $\beta$-catenin signaling. Int. J. Mol. Med. 2015, 35, 1587-1595. [CrossRef]

49. Hamam, D.; Ali, D.; Vishnubalaji, R.; Hamam, R.; Al-Nbaheen, M.; Chen, L.; Kassem, M.; Aldahmash, A.; Alajez, N.M. microRNA-320/RUNX2 axis regulates adipocytic differentiation of human mesenchymal (skeletal) stem cells. Cell Death Dis. 2014, 5, e1499. [CrossRef]

50. Zhu, L.; Chen, L.; Shi, C.-M.; Xu, G.-F.; Xu, L.-L.; Zhu, L.-L.; Guo, X.-R.; Ni, Y.; Cui, Y.; Ji, C. MiR-335, an adipogenesis-related microRNA, is involved in adipose tissue inflammation. Cell Biochem. Biophys. 2014, 68, 283-290. [CrossRef]

51. Wang, L.; Xu, L.; Xu, M.; Liu, G.; Xing, J.; Sun, C.; Ding, H. Obesity-Associated MiR-342-3p Promotes Adipogenesis of Mesenchymal Stem Cells by Suppressing CtBP2 and Releasing C/EBP $\alpha$ from CtBP2 Binding. Cell. Physiol. Biochem. 2015, 35, 2285-2298. [CrossRef] [PubMed]

52. Chen, L.; Cui, J.; Hou, J.; Long, J.; Li, C.; Liu, L. A novel negative regulator of adipogenesis: microRNA-363. Stem Cells 2014, 32, 510-520. [CrossRef] [PubMed]

53. Bork, S.; Horn, P.; Castoldi, M.; Hellwig, I.; Ho, A.D.; Wagner, W. Adipogenic differentiation of human mesenchymal stromal cells is down-regulated by microRNA-369-5p and up-regulated by microRNA-371. J. Cell. Physiol. 2011, 226, 2226-2234. [CrossRef] [PubMed]

54. Kraus, M.; Greither, T.; Wenzel, C.; Bräuer-Hartmann, D.; Wabitsch, M.; Behre, H.M. Inhibition of adipogenic differentiation of human SGBS preadipocytes by androgen-regulated microRNA miR-375. Mol. Cell. Endocrinol. 2015, 414, 177-185. [CrossRef]

55. Li, X.; Yang, Y.; Yan, R.; Xu, X.; Gao, L.; Mei, J.; Liu, J.; Wang, X.; Zhang, J.; Wu, P.; et al. miR-377-3p regulates adipogenic differentiation of human bone marrow mesenchymal stem cells by regulating LIFR. Mol. Cell. Biochem. 2018, 449, 295-303. [CrossRef]

56. Wang, Y.; Yang, L.; Liu, X.; Hong, T.; Wang, T.; Dong, A.; Li, J.; Xu, X.; Cao, L. miR-431 inhibits adipogenic differentiation of human bone marrow-derived mesenchymal stem cells via targeting insulin receptor substance 2. Stem Cell Res. Ther. 2018, 9, 231. [CrossRef]

57. Yang, L.; Shi, C.-m.; Chen, L.; Pang, L.-X.; Xu, G.-f.; Gu, N.; Zhu, L.-j.; Guo, X.-r.; Ni, Y.-h.; Ji, C.-b. The biological effects of hsa-miR-1908 in human adipocytes. Mol. Biol. Rep. 2015, 42, 927-935. [CrossRef]

58. Pang, L.; You, L.; Ji, C.; Shi, C.; Chen, L.; Yang, L.; Huang, F.; Zhou, Y.; Zhang, J.; Chen, X.; et al. miR-1275 inhibits adipogenesis via ELK1 and its expression decreases in obese subjects. J. Mol. Endocrinol. 2016, 57, 33-43. [CrossRef]

59. Elsafadi, M.; Manikandan, M.; Alajez, N.M.; Hamam, R.; Dawud, R.A.; Aldahmash, A.; Iqbal, Z.; Alfayez, M.; Kassem, M.; Mahmood, A. MicroRNA-4739 regulates osteogenic and adipocytic differentiation of immortalized human bone marrow stromal cells via targeting LRP3. Stem Cell Res. 2017, 20, 94-104. [CrossRef]

60. Tan, Y.; Gan, M.; Fan, Y.; Li, L.; Zhong, Z.; Li, X.; Bai, L.; Zhao, Y.; Niu, L.; Shang, Y.; et al. miR-10b-5p regulates 3T3-L1 cells differentiation by targeting Apol6. Gene 2019, 687, 39-46. [CrossRef] 
61. Kim, S.Y.; Kim, A.Y.; Lee, H.W.; Son, Y.H.; Lee, G.Y.; Lee, J.-W.; Lee, Y.S.; Kim, J.B. miR-27a is a negative regulator of adipocyte differentiation via suppressing PPARgamma expression. Biochem. Biophys. Res. Commun. 2010, 392, 323-328. [CrossRef] [PubMed]

62. Tan, Z.; Du, J.; Shen, L.; Liu, C.; Ma, J.; Bai, L.; Jiang, Y.; Tang, G.; Li, M.; Li, X.; et al. miR-199a-3p affects adipocytes differentiation and fatty acid composition through targeting SCD. Biochem. Biophys. Res. Commun. 2017, 492, 82-88. [CrossRef] [PubMed]

63. Shi, X.-B.; Xue, L.; Yang, J.; Ma, A.-H.; Zhao, J.; Xu, M.; Tepper, C.G.; Evans, C.P.; Kung, H.-J.; de Vere White, R.W. An androgen-regulated miRNA suppresses Bak1 expression and induces androgen-independent growth of prostate cancer cells. Proc. Natl. Acad. Sci. USA 2007, 104, 19983-19988. [CrossRef] [PubMed]

64. Yang, X.; Bemis, L.; Su, L.-J.; Gao, D.; Flaig, T.W. miR-125b Regulation of Androgen Receptor Signaling Via Modulation of the Receptor Complex Co-Repressor NCOR2. BioRes. Open Access 2012, 1, 55-62. [CrossRef] [PubMed]

65. Yang, S.; Zhang, J.; Zhang, Y.; Wan, X.; Zhang, C.; Huang, X.; Huang, W.; Pu, H.; Pei, C.; Wu, H.; et al. KDM1A triggers androgen-induced miRNA transcription via H3K4me2 demethylation and DNA oxidation. Prostate 2015, 75, 936-946. [CrossRef]

66. Sun, D.; Layer, R.; Mueller, A.C.; Cichewicz, M.A.; Negishi, M.; Paschal, B.M.; Dutta, A. Regulation of several androgen-induced genes through the repression of the miR-99a/let-7c/miR-125b-2 miRNA cluster in prostate cancer cells. Oncogene 2014, 33, 1448-1457. [CrossRef]

67. Ahram, M.; Mustafa, E.; Zaza, R.; Abu Hammad, S.; Alhudhud, M.; Bawadi, R.; Zihlif, M. Differential expression and androgen regulation of microRNAs and metalloprotease 13 in breast cancer cells. Cell Biol. Int. 2017, 41, 1345-1355. [CrossRef]

68. Sen, A.; Prizant, H.; Light, A.; Biswas, A.; Hayes, E.; Lee, H.-J.; Barad, D.; Gleicher, N.; Hammes, S.R. Androgens regulate ovarian follicular development by increasing follicle stimulating hormone receptor and microRNA-125b expression. Proc. Natl. Acad. Sci. USA 2014, 111, 3008-3013. [CrossRef]

69. Ribas, J.; Ni, X.; Haffner, M.; Wentzel, E.A.; Salmasi, A.H.; Chowdhury, W.H.; Kudrolli, T.A.; Yegnasubramanian, S.; Luo, J.; Rodriguez, R.; et al. miR-21: An androgen receptor-regulated microRNA that promotes hormone-dependent and hormone-independent prostate cancer growth. Cancer Res. 2009, 69, 7165-7169. [CrossRef]

70. Ribas, J.; Lupold, S.E. The transcriptional regulation of miR-21, its multiple transcripts, and their implication in prostate cancer. Cell Cycle 2010, 9, 923-929. [CrossRef]

71. Mishra, S.; Deng, J.J.; Gowda, P.S.; Rao, M.K.; Lin, C.-L.; Chen, C.L.; Huang, T.; Sun, L.-Z. Androgen receptor and microRNA-21 axis downregulates transforming growth factor beta receptor II (TGFBR2) expression in prostate cancer. Oncogene 2014, 33, 4097-4106. [CrossRef] [PubMed]

72. Teng, Y.; Litchfield, L.M.; Ivanova, M.M.; Prough, R.A.; Clark, B.J.; Klinge, C.M. Dehydroepiandrosterone-induces miR-21 transcription in HepG2 cells through estrogen receptor $\beta$ and androgen receptor. Mol. Cell. Endocrinol. 2014, 392, 23-36. [CrossRef] [PubMed]

73. Casaburi, I.; Cesario, M.G.; Donà, A.; Rizza, P.; Aquila, S.; Avena, P.; Lanzino, M.; Pellegrino, M.; Vivacqua, A.; Tucci, P.; et al. Androgens downregulate miR-21 expression in breast cancer cells underlining the protective role of androgen receptor. Oncotarget 2016, 7, 12651-12661. [CrossRef] [PubMed]

74. Cao, P.; Deng, Z.; Wan, M.; Huang, W.; Cramer, S.D.; Xu, J.; Lei, M.; Sui, G. MicroRNA-101 negatively regulates Ezh2 and its expression is modulated by androgen receptor and HIF-1alpha/HIF-1beta. Mol. Cancer 2010, 9, 108. [CrossRef]

75. Ma, X.; Hayes, E.; Biswas, A.; Seger, C.; Prizant, H.; Hammes, S.R.; Sen, A. Androgens Regulate Ovarian Gene Expression Through Modulation of Ezh2 Expression and Activity. Endocrinology 2017, 158, 2944-2954. [CrossRef]

76. Li, J.; Xie, M.; Wang, X.; Ouyang, X.; Wan, Y.; Dong, G.; Yang, Z.; Yang, J.; Yue, J. Sex hormones regulate cerebral drug metabolism via brain miRNAs: Down-regulation of brain CYP2D by androgens reduces the analgesic effects of tramadol. Br. J. Pharmacol. 2015, 172, 4639-4654. [CrossRef]

77. Guo, J.; Huang, X.; Wang, H.; Yang, H. Celastrol Induces Autophagy by Targeting AR/miR-101 in Prostate Cancer Cells. PLoS ONE 2015, 10, 0140745. [CrossRef]

78. Zheng, C.; Yinghao, S.; Li, J. MiR-221 expression affects invasion potential of human prostate carcinoma cell lines by targeting DVL2. Med. Oncol. 2012, 29, 815-822. [CrossRef] 
79. Gui, B.; Hsieh, C.-L.; Kantoff, P.W.; Kibel, A.S.; Jia, L. Androgen receptor-mediated downregulation of microRNA-221 and -222 in castration-resistant prostate cancer. PLoS ONE 2017, 12, e0184166. [CrossRef]

80. Sun, T.; Wang, Q.; Balk, S.; Brown, M.; Lee, G.-S.M.; Kantoff, P. The role of microRNA-221 and microRNA-222 in androgen-independent prostate cancer cell lines. Cancer Res. 2009, 69, 3356-3363. [CrossRef]

81. Sun, T.; Yang, M.; Chen, S.; Balk, S.; Pomerantz, M.; Hsieh, C.-L.; Brown, M.; Lee, G.-S.M.; Kantoff, P.W. The altered expression of MiR-221/-222 and MiR-23b/-27b is associated with the development of human castration resistant prostate cancer. The Prostate 2012, 72, 1093-1103. [CrossRef] [PubMed]

82. Sun, T.; Wang, X.; He, H.H.; Sweeney, C.J.; Liu, S.X.; Brown, M.; Balk, S.; Lee, G.-S.; Kantoff, P.W. MiR-221 promotes the development of androgen independence in prostate cancer cells via downregulation of HECTD2 and RAB1A. Oncogene 2014, 33, 2790-2800. [CrossRef] [PubMed]

83. Sun, T.; Du, S.-Y.; Armenia, J.; Qu, F.; Fan, J.; Wang, X.; Fei, T.; Komura, K.; Liu, S.X.; Lee, G.-S.M.; et al. Expression of lncRNA MIR222HG co-transcribed from the miR-221/222 gene promoter facilitates the development of castration-resistant prostate cancer. Oncogenesis 2018, 7, 30. [CrossRef]

84. Fletcher, C.E.; Dart, D.A.; Sita-Lumsden, A.; Cheng, H.; Rennie, P.S.; Bevan, C.L. Androgen-regulated processing of the oncomir MiR-27a, which targets Prohibitin in prostate cancer. Hum. Mol. Genet. 2012, 21, 3112-3127. [CrossRef] [PubMed]

85. Mo, W.; Zhang, J.; Li, X.; Meng, D.; Gao, Y.; Yang, S.; Wan, X.; Zhou, C.; Guo, F.; Huang, Y.; et al. Identification of Novel AR-Targeted MicroRNAs Mediating Androgen Signalling through Critical Pathways to Regulate Cell Viability in Prostate Cancer. PLoS ONE 2013, 8, e56592. [CrossRef] [PubMed]

86. Wan, X.; Huang, W.; Yang, S.; Zhang, Y.; Zhang, P.; Kong, Z.; Li, T.; Wu, H.; Jing, F.; Li, Y. Androgen-induced miR-27A acted as a tumor suppressor by targeting MAP2K4 and mediated prostate cancer progression. Int. J. Biochem. Cell Biol. 2016, 79, 249-260. [CrossRef]

87. B Arroyo, A.; Salloum-Asfar, S.; Pérez-Sánchez, C.; Teruel-Montoya, R.; Navarro, S.; García-Barberá, N.; Luengo-Gil, G.; Roldán, V.; Hansen, J.-B.; López-Pedrera, C.; et al. Regulation of TFPI $\alpha$ expression by $\mathrm{miR}-27 \mathrm{a} / \mathrm{b}-3 \mathrm{p}$ in human endothelial cells under normal conditions and in response to androgens. Sci. Rep. 2017, 7, 43500. [CrossRef]

88. Wang, M.; Liu, M.; Sun, J.; Jia, L.; Ma, S.; Gao, J.; Xu, Y.; Zhang, H.; Tsang, S.Y.; Li, X. MicroRNA-27a-3p affects estradiol and androgen imbalance by targeting Creb1 in the granulosa cells in mouse polycytic ovary syndrome model. Reprod. Biol. 2017, 17, 295-304. [CrossRef]

89. Jalava, S.E.; Urbanucci, A.; Latonen, L.; Waltering, K.K.; Sahu, B.; Jänne, O.A.; Seppälä, J.; Lähdesmäki, H.; Tammela, T.L.J.; Visakorpi, T. Androgen-regulated miR-32 targets BTG2 and is overexpressed in castration-resistant prostate cancer. Oncogene 2012, 31, 4460-4471. [CrossRef]

90. Dang, Q.; Li, L.; Xie, H.; He, D.; Chen, J.; Song, W.; Chang, L.S.; Chang, H.-C.; Yeh, S.; Chang, C. Anti-androgen enzalutamide enhances prostate cancer neuroendocrine (NE) differentiation via altering the infiltrated mast cells $\rightarrow$ androgen receptor (AR) $\rightarrow$ miRNA32 signals. Mol. Oncol. 2015, 9, 1241-1251. [CrossRef]

91. Tang, X.; Tang, X.; Gal, J.; Kyprianou, N.; Zhu, H.; Tang, G. Detection of MicroRNAs in Prostate Cancer Cells by MicroRNA Array. In Advanced Structural Safety Studies; Springer Science and Business Media LLC: Berlin, Germany, 2011; Volume 732, pp. 69-88.

92. Williams, L.V.; Veliceasa, D.; Vinokour, E.; Volpert, O.V. miR-200b Inhibits Prostate Cancer EMT, Growth and Metastasis. PLoS ONE 2013, 8, e83991. [CrossRef] [PubMed]

93. Jacob, S.; Nayak, S.; Fernandes, G.; Barai, R.S.; Menon, S.; Chaudhari, U.K.; Kholkute, S.D.; Sachdeva, G. Androgen receptor as a regulator of ZEB2 expression and its implications in epithelial-to-mesenchymal transition in prostate cancer. Endocr. -Relat. Cancer 2014, 21, 473-486. [CrossRef] [PubMed]

94. Liu, Y.-N.; Yin, J.; Barrett, B.; Sheppard-Tillman, H.; Li, D.; Casey, O.M.; Fang, L.; Hynes, P.G.; Ameri, A.H.; Kelly, K. Loss of Androgen-Regulated MicroRNA 1 Activates SRC and Promotes Prostate Cancer Bone Metastasis. Mol. Cell. Biol. 2015, 35, 1940-1951. [CrossRef] [PubMed]

95. Siu, M.-K.; Suau, F.; Chen, W.-Y.; Tsai, Y.-C.; Tsai, H.-Y.; Yeh, H.-L.; Liu, Y.-N. KLF4 functions as an activator of the androgen receptor through reciprocal feedback. Oncogenesis 2016, 5, e282. [CrossRef] [PubMed]

96. Siu, M.K.; Chen, W.-Y.; Tsai, H.-Y.; Chen, H.-Y.; Yin, J.J.; Chen, C.-L.; Tsai, Y.-C.; Liu, Y.-N. TCF7 is suppressed by the androgen receptor via microRNA-1-mediated downregulation and is involved in the development of resistance to androgen deprivation in prostate cancer. Prostate Cancer Prostatic Dis. 2017, 20, 172-178. [CrossRef] [PubMed] 
97. Chen, W.-Y.; Tsai, Y.-C.; Siu, M.K.; Yeh, H.-L.; Chen, C.-L.; Yin, J.J.; Huang, J.; Liu, Y.-N. Inhibition of the androgen receptor induces a novel tumor promoter, ZBTB46, for prostate cancer metastasis. Oncogene 2017, 36, 6213-6224. [CrossRef]

98. Nguyen, H.C.N.; Xie, W.; Yang, M.; Hsieh, C.-L.; Drouin, S.; Lee, G.-S.M.; Kantoff, P.W. Expression differences of circulating microRNAs in metastatic castration resistant prostate cancer and low-risk, localized prostate cancer. Prostate 2013, 73, 346-354. [CrossRef]

99. Tiryakioglu, D.; Bilgin, E.; Holdenrieder, S.; Dalay, N.; Gezer, U. miR-141 and miR-375 induction and release are different from PSA mRNA and PCA3 upon androgen stimulation of LNCaP cells. Biomed. Rep. 2013, 1, 802-806. [CrossRef]

100. Chu, M.; Chang, Y.; Li, P.; Guo, Y.; Zhang, K.; Gao, W. Androgen receptor is negatively correlated with the methylation-mediated transcriptional repression of miR-375 in human prostate cancer cells. Oncol. Rep. 2014, 31, 34-40. [CrossRef]

101. Lyu, S.; Yu, Q.; Ying, G.; Wang, S.; Wang, Y.; Zhang, J.; Niu, Y. Androgen receptor decreases CMYC and KRAS expression by upregulating let-7a expression in ER-, PR-, AR+ breast cancer. Int. J. Oncol. 2014, 44, 229-237. [CrossRef]

102. Ramberg, H.; Alshbib, A.; Berge, V.; Svindland, A.; Taskén, K.A. Regulation of PBX3 expression by androgen and Let-7d in prostate cancer. Mol. Cancer 2011, 10, 50. [CrossRef] [PubMed]

103. Kroiss, A.; Vincent, S.; Decaussin-Petrucci, M.; Meugnier, E.; Viallet, J.; Ruffion, A.; Chalmel, F.; Samarut, J.; Allioli, N. Androgen-regulated microRNA-135a decreases prostate cancer cell migration and invasion through downregulating ROCK1 and ROCK2. Oncogene 2015, 34, 2846-2855. [CrossRef] [PubMed]

104. Wan, X.; Pu, H.; Huang, W.; Yang, S.; Zhang, Y.; Kong, Z.; Yang, Z.; Zhao, P.; Li, A.; Li, T.; et al. Androgen-induced miR-135a acts as a tumor suppressor through downregulating RBAK and MMP11, and mediates resistance to androgen deprivation therapy. Oncotarget 2016, 7, 51284-51300. [CrossRef] [PubMed]

105. Waltering, K.K.; Porkka, K.P.; Jalava, S.E.; Urbanucci, A.; Kohonen, P.J.; Latonen, L.M.; Kallioniemi, O.P.; Jenster, G.; Visakorpi, T. Androgen regulation of micro-RNAs in prostate cancer. Prostate 2011, 71, 604-614. [CrossRef]

106. Pasqualini, L.; Bu, H.; Puhr, M.; Narisu, N.; Rainer, J.; Schlick, B.; Schäfer, G.; Angelova, M.; Trajanoski, Z.; Börno, S.T.; et al. miR-22 and miR-29a Are Members of the Androgen Receptor Cistrome Modulating LAMC1 and Mcl-1 in Prostate Cancer. Mol. Endocrinol. 2015, 29, 1037-1054. [CrossRef]

107. Guo, J.; Mei, Y.; Li, K.; Huang, X.; Yang, H. Downregulation of miR-17-92a cluster promotes autophagy induction in response to celastrol treatment in prostate cancer cells. Biochem. Biophys. Res. Commun. 2016, 478, 804-810. [CrossRef]

108. Chen, P.-J.; Yeh, S.-H.; Liu, W.-H.; Lin, C.-C.; Huang, H.-C.; Chen, C.-L.; Chen, D.-S.; Chen, P.-J. Androgen pathway stimulates MicroRNA-216a transcription to suppress the tumor suppressor in lung cancer-1 gene in early hepatocarcinogenesis. Hepatology 2012, 56, 632-643. [CrossRef]

109. Miyazaki, T.; Ikeda, K.; Sato, W.; Horie-Inoue, K.; Okamoto, K.; Inoue, S. MicroRNA Library-Based Functional Screening Identified Androgen-Sensitive miR-216a as a Player in Bicalutamide Resistance in Prostate Cancer. J. Clin. Med. 2015, 4, 1853-1865. [CrossRef]

110. Ma, W.; Hu, S.; Yao, G.; Xie, S.; Ni, M.; Liu, Q.; Gao, X.; Zhang, J.; Huang, X.; Zhang, Y. An androgen receptor-microrna-29a regulatory circuitry in mouse epididymis. J. Biol. Chem. 2013, 288, 29369-29381. [CrossRef]

111. Takayama, K.-I.; Misawa, A.; Suzuki, T.; Takagi, K.; Hayashizaki, Y.; Fujimura, T.; Homma, Y.; Takahashi, S.; Urano, T.; Inoue, S. TET2 repression by androgen hormone regulates global hydroxymethylation status and prostate cancer progression. Nat. Commun. 2015, 6, 8219. [CrossRef]

112. Nicholls, P.K.; Harrison, C.A.; Walton, K.L.; McLachlan, R.I.; O’Donnell, L.; Stanton, P.G. Hormonal Regulation of Sertoli Cell Micro-RNAs at Spermiation. Endocrinology 2011, 152, 1670-1683. [CrossRef] [PubMed]

113. Shao, X.; Liu, Y.; Liu, M.; Wang, Y.; Yan, L.; Wang, H.; Ma, L.; Li, Y.-X.; Zhao, Y.; Wang, Y.-L. Testosterone Represses Estrogen Signaling by Upregulating miR-22: A Mechanism for Imbalanced Steroid Hormone Production in Preeclampsia. Hypertension 2017, 69, 721-730. [CrossRef] [PubMed]

114. Chu, M.; Chang, Y.; Guo, Y.; Wang, N.; Cui, J.; Gao, W.-Q. Regulation and Methylation of Tumor Suppressor MiR-124 by Androgen Receptor in Prostate Cancer Cells. PLoS ONE 2015, 10, e0116197. [CrossRef] [PubMed] 
115. Nilsson, E.M.; Laursen, K.B.; Whitchurch, J.; McWilliam, A.; Ødum, N.; Persson, J.L.; Heery, D.M.; Gudas, L.J.; Mongan, N.P. MiR137 is an androgen regulated repressor of an extended network of transcriptional coregulators. Oncotarget 2015, 6, 35710-35725. [CrossRef]

116. Gezer, U.; Tiryakioglu, D.; Bilgin, E.; Dalay, N.; Holdenrieder, S. Androgen Stimulation of PCA3 and miR-141 and Their Release from Prostate Cancer Cells. Cell J. 2015, 16, 488-493.

117. Chen, Y.; Sun, Y.; Rao, Q.; Xu, H.; Li, L.; Chang, C. Androgen receptor (AR) suppresses miRNA-145 to promote renal cell carcinoma (RCC) progression independent of VHL status. Oncotarget 2015, 6, 31203-31215. [CrossRef]

118. Murata, T.; Takayama, K.; Katayama, S.; Urano, T.; Horie-Inoue, K.; Ikeda, K.; Takahashi, S.; Kawazu, C.; Hasegawa, A.; Ouchi, Y.; et al. miR-148a is an androgen-responsive microRNA that promotes LNCaP prostate cell growth by repressing its target CAND1 expression. Prostate Cancer Prostatic Dis. 2010, 13, 356-361. [CrossRef]

119. Yao, J.; Xu, C.; Fang, Z.; Li, Y.; Liu, H.; Wang, Y.; Xu, C.; Sun, Y. Androgen receptor regulated microRNA miR-182-5p promotes prostate cancer progression by targeting the ARRDC3/ITGB4 pathway. Biochem. Biophys. Res. Commun. 2016, 474, 213-219. [CrossRef]

120. Huang, Q.; Sun, Y.; Ma, X.; Gao, Y.; Li, X.; Niu, Y.; Zhang, X.; Chang, C. Androgen receptor increases hematogenous metastasis yet decreases lymphatic metastasis of renal cell carcinoma. Nat. Commun. 2017, 8, 918. [CrossRef]

121. Xu, S.; Wang, T.; Song, W.; Jiang, T.; Zhang, F.; Yin, Y.; Jiang, S.-W.; Wu, K.; Yu, Z.; Wang, C.; et al. The inhibitory effects of AR/miR-190a/YB-1 negative feedback loop on prostate cancer and underlying mechanism. Sci. Rep. 2015, 5, 13528. [CrossRef]

122. Jia, L.; Gui, B.; Zheng, D.; Decker, K.F.; Tinay, I.; Tan, M.; Wang, X.; Kibel, A.S. Androgen receptor-regulated miRNA-193a-3p targets AJUBA to promote prostate cancer cell migration. Prostate 2017, 77, 1000-1011. [CrossRef] [PubMed]

123. Ding, M.; Lin, B.; Li, T.; Liu, Y.; Li, Y.; Zhou, X.; Miao, M.; Gu, J.; Pan, H.; Yang, F.; et al. A dual yet opposite growth-regulating function of miR-204 and its target XRN1 in prostate adenocarcinoma cells and neuroendocrine-like prostate cancer cells. Oncotarget 2015, 6, 7686-7700. [CrossRef] [PubMed]

124. Nakano, K.; Miki, Y.; Hata, S.; Ebata, A.; Takagi, K.; McNamara, K.M.; Sakurai, M.; Masuda, M.; Hirakawa, H.; Ishida, T.; et al. Identification of androgen-responsive microRNAs and androgen-related genes in breast cancer. Anticancer Res. 2013, 33, 4811-4819. [PubMed]

125. Meng, D.; Yang, S.; Wan, X.; Zhang, Y.; Huang, W.; Zhao, P.; Li, T.; Wang, L.; Huang, Y.; Li, Y. A transcriptional target of androgen receptor, miR-421 regulates proliferation and metabolism of prostate cancer cells. Int. J. Biochem. Cell Biol. 2016, 73, 30-40. [CrossRef] [PubMed]

126. Panneerdoss, S.; Chang, Y.-F.; Buddavarapu, K.C.; Chen, H.-I.H.; Shetty, G.; Wang, H.; Chen, Y.; Kumar, T.R.; Rao, M.K. Androgen-Responsive MicroRNAs in Mouse Sertoli Cells. PLoS ONE 2012, 7, e41146. [CrossRef] [PubMed]

127. Panneerdoss, S.; Viswanadhapalli, S.; Abdelfattah, N.; Onyeagucha, B.C.; Timilsina, S.; Mohammad, T.A.; Chen, Y.; Drake, M.; Vuori, K.; Kumar, T.R.; et al. Cross-talk between miR-471-5p and autophagy component proteins regulates LC3-associated phagocytosis (LAP) of apoptotic germ cells. Nat. Commun. 2017, 8, 598. [CrossRef]

128. Ayub, S.G.; Kaul, D.; Ayub, T. An androgen-regulated miR-2909 modulates TGF $\beta$ signalling through $\mathrm{AR} / \mathrm{miR}-2909$ axis in prostate cancer. Gene 2017, 631, 1-9. [CrossRef]

129. Wang, R.-F.; Wang, Z.-F.; Cheng, Q.; Wang, G.-R.; Bai, Z.-M. Androgen receptor suppresses prostate cancer cell invasion via altering the miR-4496/ $\beta$-catenin signals. Biochem. Biophys. Res. Commun. 2018, 504, 82-88. [CrossRef]

130. Wang, T.; Li, M.; Guan, J.; Li, P.; Wang, H.; Guo, Y.; Shuai, S.; Li, X. MicroRNAs miR-27a and miR-143 Regulate Porcine Adipocyte Lipid Metabolism. Int. J. Mol. Sci. 2011, 12, 7950-7959. [CrossRef]

131. Kang, T.; Lu, W.; Xu, W.; Anderson, L.; Bacanamwo, M.; Thompson, W.; Chen, Y.E.; Liu, D. MicroRNA-27 (miR-27) Targets Prohibitin and Impairs Adipocyte Differentiation and Mitochondrial Function in Human Adipose-derived Stem Cells. J. Biol. Chem. 2013, 288, 34394-34402. [CrossRef]

132. Qadir, A.S.; Woo, K.M.; Ryoo, H.-M.; Baek, J.-H. Insulin suppresses distal-less homeobox 5 expression through the up-regulation of microRNA-124 in 3T3-L1 cells. Exp. Cell Res. 2013, 319, 2125-2134. [CrossRef] [PubMed] 
133. Allan, C.A.; Strauss, B.J.G.; Forbes, E.A.; McLachlan, R.I.; Burger, H.G. Testosterone Therapy Prevents Gain in Visceral Adipose Tissue and Loss of Skeletal Muscle in Nonobese Aging Men. J. Clin. Endocrinol. Metab. 2008, 93, 139-146. [CrossRef] [PubMed]

134. Behre, H.M.; Tammela, T.L.J.; Arver, S.; Tolrá, J.R.; Bonifacio, V.; Lamche, M.; Kelly, J.; Hiemeyer, F.; Giltay, E.J.; Gooren, L.J. A randomized, double-blind, placebo-controlled trial of testosterone gel on body composition and health-related quality-of-life in men with hypogonadal to low-normal levels of serum testosterone and symptoms of androgen deficiency over 6 months with 12 months open-label follow-up. Aging Male 2012, 15, 198-207. [PubMed]

(C) 2019 by the authors. Licensee MDPI, Basel, Switzerland. This article is an open access article distributed under the terms and conditions of the Creative Commons Attribution (CC BY) license (http://creativecommons.org/licenses/by/4.0/). 